\title{
Pengembangan Multimedia Online pada Muatan Pelajaran IPA
}

\author{
Putu Krisna S. Dharma ${ }^{1 *}$, Anak Agung Gede Agung² iD \\ 1,2 Jurusan Pendidikan Dasar, Universitas Pendidikan Ganesha, Singaraja, Indonesia \\ *Corresponding author: agungtps2056@gmail.com
}

\begin{abstract}
Abstrak
Penelitian pengembangan ini dilatarbelakangi oleh permasalahan yang terdapat pada pembelajaran daring, khususnya pada media dan alat evaluasi pembelajaran. Tujuan penelitian ini adalah untuk mengembangkan Multimedia Online pada muatan pelajaran IPA. Subjek pada penelitian ini yaitu ahli isi muatan pelajaran, ahli desain instruksional, ahli media pembelajaran, dan siswa kelas V SD. Penelitian ini menggunakan model pengembangan ADDIE (Analyze, Design, Development, Implementation, Evaluation). Data dikumpulkan dengan menggunakan metode kuesioner. Analisis data menggunakan metode analisis deskriptif kuantitatif. Hasil analisis data diperoleh dengan presentase sebagai berikut ahli isi muatan pelajaran IPA memperoleh skor 94,44 dengan kualifikasi sangat baik, ahli desain instruksional memperoleh skor 90,00 dengan kualifikasi sangat baik, ahli media pembelajaran memperoleh skor 87,50 dengan kualifikasi baik, dan hasil uji coba perorangan memperoleh skor 92,67 dengan kualifikasi sangat baik. Berdasarkan hasil analisis data uji produk oleh para ahli (ahli isi muatan pelajaran, ahli desain instruksional, ahli media pembelajaran) dan hasil uji coba perorangan, dapat disimpulkan bahwa produk Multimedia Online ini layak digunakan pada muatan pelajaran IPA kelas V.
\end{abstract}

Kata kunci: Multimedia Online, ADDIE, IPA

\section{Abstract}

This development research is motivated by problems in online learning, especially in media and learning evaluation tools. The purpose of this research is to develop Multimedia Online on the content of science lessons. The subjects in this study were lesson content experts, instructional design experts, learning media experts, and grade $V$ elementary students. This research uses ADDIE development model (Analyze, Design, Development, Implementation, Evaluation). The data is collected using questionnaire methods. Data analysis using quantitative descriptive analysis methods. The results of data analysis are obtained by percentage as follows. IPA content experts scored 94.44 with excellent qualifications, instructional design experts scored 90.00 with excellent qualifications, learning media experts scored 87.50 with good qualifications, and individual trial results scored 92.67 with excellent qualifications. Based on the results of analysis of product test data by experts (lesson content experts, instructional design experts, learning media experts) and individual trial results, it can be concluded that this Multimedia Online product is worth using on science class V lesson content.

Keywords: Online Multimedia; ADDIE; Science

$\begin{array}{ll}\text { History: } & \\ \text { Received } & \text { : xx mm yyyy } \\ \text { Revised } & \text { : xx mm yyyy } \\ \text { Accepted } & \text { : xx mm yyyy } \\ \text { Published } & \text { : } 25 \text { Maret } 2021\end{array}$

Publisher: Undiksha Press

Licensed: This work is licensed under a Creative Commons Attribution 4.0 License (c) (i) (?)

\section{Pendahuluan}

Abad 21 dikenal sebagai era globalisasi dimana ilmu pengetahuan dan teknologi (IPTEK) berkembang begitu pesat (Budiman, 2017; Santika, 2021). Proses digitalisasi memberikan dampak yang sangat besar bagi dunia pendidikan (Santika, 2021). Perkembangan teknologi informasi juga memicu perubahan pada pola pembelajaran (Sudihartono, 2020). Teknologi dapat digunakan sebagai penunjang dalam proses pembelajaran. Guru diharapkan mampu memberikan suatu inovasi dalam mengembangkan media pembelajaran menjadi lebih baik dan menarik. Proses pembelajaran dapat 
dilaksanakan secara fleksibel artinya dapat dilaksanakan kapanpun dan dimanapun. Teknologi merupakan sangat penting dalam proses pembelajaran.

Saat ini, Indonesia sedang terserang wabah virus yang berasal dari Wuhan, Cina bernama Corona Virus Disease atau Covid-19 (Muhammad, 2020; Susilo et al., 2020). Virus ini menimbulkan banyak masalah dalam kehidupan masyarakat Indonesia di berbagai bidang. Pendidikan sebagai bidang yang berperan dalam peningkatan sumber daya manusia (SDM) juga ikut mendapatkan masalah yang cukup berarti. Kementrian Pendidikan dan Kebudayaan (Kemendikbud) menerbitkan surat edaran tentang pelaksanaan kegiatan Belajar Dari Rumah (BDR). Hal tersebut menyebabkan sistem pembelajaran mengalami perubahan. Sistem pembelajaran secara luar jaringan (luring), dialihkan menjadi sistem pembelajaran dalam jaringan (daring). Sistem pembelajaran daring ini menimbulkan banyak permasalahan baik kepada guru, orang tua siswa, maupun siswa sendiri terutama pada proses pembelajaran. Hal senada dengan hasil wawancara yang telah dilaksanakan dengan kepala sekolah SDN 1 Bitera dan beberapa guru disana. Pembelajaran daring ini membuat guru menjadi kesulitan untuk menentukan strategi pembelajaran terutama pada media pembelajaran dan juga alat evaluasi pembelajaran. Guru hanya memberikan penugasan-penugasan kepada siswa, tanpa menggunakan alat peraga atau media pembelajaran, sehingga pelaksanaan pembelajaran menjadi kurang optimal. Dalam pelaksanaan pembelajaran daring, sangat sulit menerapkan media pembelajaran yang berbentuk tiga dimensi sehingga untuk membantu agar siswa lebih mudah memahami makna materi yang disajikan dalam pembelajaran dibutuhkan media yang sesuai dengan kebutuhan siswa dan mampu diterapkan ke dalam pembelajaran daring.

Untuk mengatasi beberapa permasalahan tersebut maka salah satu solusi yang dapat diterapkan yaitu dengan menggunakan media pembelajaran. Media pembelajaran memiliki peran penting dalam kegiatan pembelajaran, berfungsi sebagai sarana dalam menyampaikan materi dan pengetahuan yang hendak dibangun melalui kegiatan bermain (Rosidah, 2016; Saurina, 2016; Yusnia, 2019). Penerapan media pembelajaran di SD sangat penting karena pada tingkat sekolah dasar memiliki kemampuan yang terbatas dalam memahami materi yang bersifat abstrak. Salah satu materi pembelajaran yang dimaksudkan adalah pembelajaran IPA, pembelajaran IPA membutuhkan sebuah media pembelajaran yang digunakan untuk menjelaskan atau membelajarkan siswa sehingga siswa mampu mengkongkritkan materi tersebut. Perkembangan teknologi yang semakin modern dapat membantu seseorang dalam menciptakan inovasi-inovasi baru dan meningkatkan kreatifitas sehingga dapat menciptakan media pembelajaran yang menarik dalam bentuk audio, visual, dan gerak (Novita, Sukmanasa, 2019; Widjiningsih, Sugiyono, 2014).

Salah satu media pembelajaran yang dapat dikembangkan yaitu multimedia online pada pembelajaran IPA. Multimedia merupak penggunaan teknologi untuk menyajikan dan menggabungkan teks, suara, gambar, animasi dan video dengan alat bantu dan koneksi (link) sehingga pengguna dapat berinteraksi, berkarya dan berkomunikasi (Ahmadi et al., 2017). Pembaharuan yang terus terjadi menggiring pendidikan ke arah perubahan yang berkesinambungan. Salah satu bentuk dari perkembangan teknologi dalam pendidikan adalah Multimedia. Multimedia adalah suatu perantara yang digunakan untuk membantu menyampaikan informasi yang dikemas dalam bentuk audio visual (Simarmata \& Mujiarto, 2019). seorang akan belajar dengan baik jika pembelajaran menggunakan unsur suara, gambar, teks, video, dan animasi (Novianto, dkk. 2018). Multimedia online dapat diterapkan pada seluruh mata pelajaran salah satunya pembelajaran IPA. IPA merupakan ilmu yang memiliki karakteristik khusus yaitu mempelajari hubungan sebab akibat dari fenomena alam yang faktual (factual), baik berupa kenyataan (reality) atau kejadian (event) (Wisudawati \& Sulistyowati, 2015). IPA menitikberatkan pada kemampuan berfikir kritis agar siswa dapat mengingat, mengidentifikasi, serta mengaplikasikannya secara ilmiah (Permana \& Nourmavita, 2017). 
Temuan penelitian yang mendukung menyatakan multimedia dapat meningkatkan berpikir kreatif pada siswa dan memudahkan siswa dalam menyerap informasi (Rasyid et al., 2016). Penelitian ini didukung dari hasil penelitian yang telah dilakukan sebelumnya oleh yang menggunakan aplikasi Quizizz untuk mengembangankan bahan ajar LKPD. Penelitian tersebut menunjukan bahwa LKPD yang dikembangkan layak digunakan (Kinanti \& Subagio, 2020). Menggunakan aplikasi Quizizz dalam pembelajaran juga terbukti meningkatkan hasil belajar (Jati, 2020;Mulyati \& Evendi, (2020). Produk Multimedia Online ini dikembangkan menggunakan aplikasi Quizizz. Quiziz merupakan web tool yang digunakan untuk membuat game kuis interaktif yang bisa digunakan pada proses pembelajaran (Yana et al., 2019). Game atau permainan akan meningkatkan motivasi dan rasa ingin tahu siswa, karena game salah satu media pembelajaran yang bersifat menarik, interaktif, komunikatif, dan menantang (Citra \& Rosy, 2020). Pemilihan media aplikasi pembelajaran ini karena dalam proses pembelajaran daring, sehingga diperlukan suatu media yang dapat menunjang pembelajaran tersebut dan dapat diakses dengan mudah/praktis. Penelitian ini bertujuan untuk mendeskripsikan proses rancang bangun dari produk Multimedia online pada pembelajaran IPA dan mengetahui hasil validasi produk Multimedia online menurut hasil review para ahli dan uji coba perorangan. Diharapkan multimedia yang dikembangkan dapat membantu siswa dalam belajar sehingga berdampak pada hasil belajar siswa yang meningkat.

\section{Metode}

Penelitian pengembangan ini menggunakan model ADDIE yang terdiri dari lima tahap yaitu analisis (analyze), perancangan (design), pengembangan (development), implementasi (implementation), dan evaluasi (evaluation) (Tegeh \& Kirna, 2013). Penelitian ini hanya bisa dilakukan sampai pada uji kelayakan atau validasi produk dikarenakan situasi pandemi Covid-19. Penelitian ini dilakukan dengan subjek penelitian adalah satu dosen sebagai ahli isi muatan pelajaran, satu dosen sebagai ahli desain instruksional dan ahli media pembelajaran, dan siswa kelas V di SD Negeri 1 Bitera. Metode pengumpulan data yang digunakan dalam penelitian ini menggunakan metode kuesioner. Metode kuesioner ini digunakan pada tahap validasi produk yang terdiri dari ahli isi muatan pelajaran, ahli desain instruksional, ali media pembelajaran, dan tahap uji coba perorangan. Instrumen yang digunakan untuk mengumpulkan data penelitian pengembangan ini berupa kuesioner. Adapun kisi-kisi instrumen penilaian ahli isi muatan pelajaran, ahli desain instruksional, ahli media pembelajaran, dan uji coba perorangan, tersaji pada Tabel 1, 2, 3, dan 4 .

Tabel 1. Kisi-Kisi Instrumen Ahli Isi Muatan Pelajaran

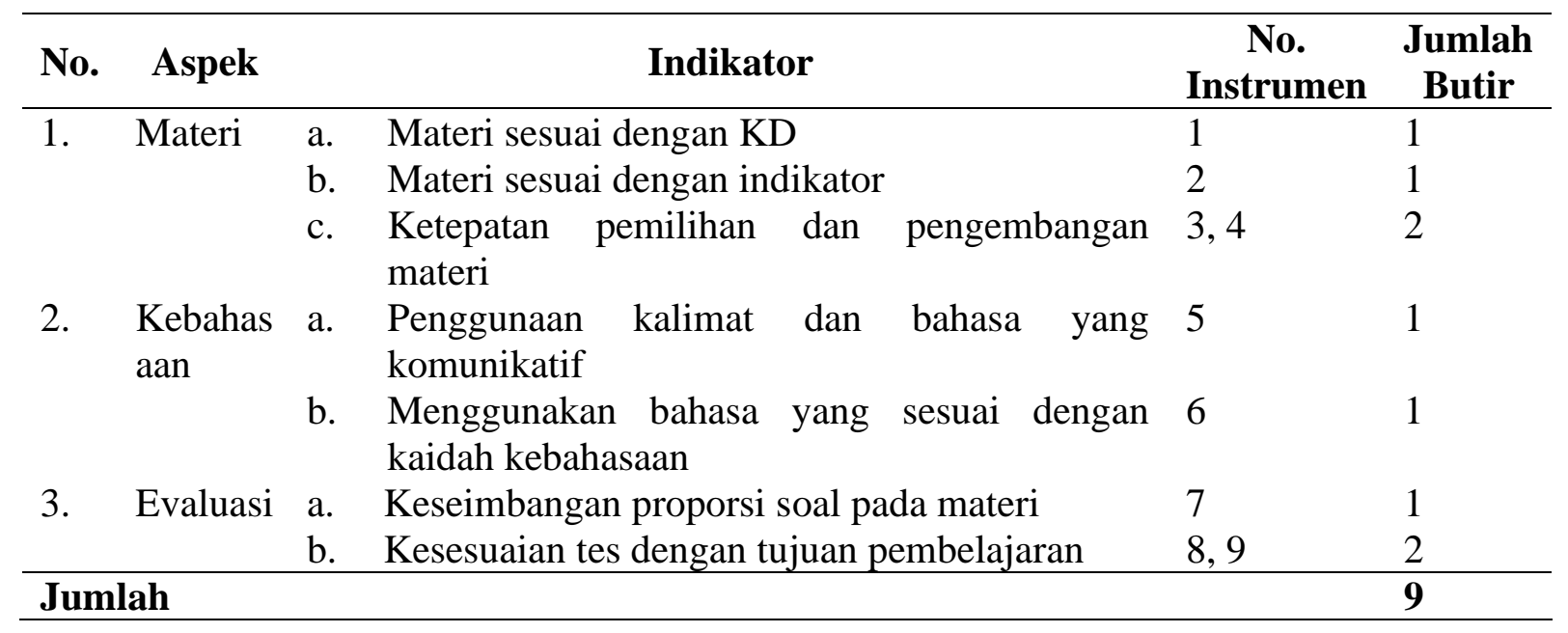


Tabel 2. Kisi-Kisi Instrumen Ahli Desain Instruksional

\begin{tabular}{|c|c|c|c|c|}
\hline No. & Aspek & Indikator & $\begin{array}{c}\text { No. } \\
\text { Instrumen }\end{array}$ & $\begin{array}{c}\text { Jumlah } \\
\text { Butir }\end{array}$ \\
\hline 1. & Tujuan & a. Kejelasan tujuan pembelajaran & 1 & 1 \\
\hline 2. & Strategi & $\begin{array}{l}\text { a. Kesesuaian strategi pembelajaran dengan } \\
\text { kondisi di sekolah }\end{array}$ & 2 & 1 \\
\hline 3. & Evaluasi & $\begin{array}{l}\text { b. Ketepatan penggunaan strategi pembelajaran } \\
\text { a. Kejelasan petunjuk pengerjaan soal } \\
\text { b. Kualitas soal }\end{array}$ & $\begin{array}{l}3,4,5 \\
6 \\
7\end{array}$ & $\begin{array}{l}3 \\
1 \\
1\end{array}$ \\
\hline \multicolumn{3}{|c|}{ Jumlah } & & 7 \\
\hline
\end{tabular}

Tabel 3. Kisi-Kisi Instrumen Ahli Media Pembelajaran

\begin{tabular}{|c|c|c|c|c|}
\hline No. & Aspek & Indikator & $\begin{array}{l}\text { No. } \\
\text { Instrumen }\end{array}$ & $\begin{array}{l}\text { Jumlah } \\
\text { Butir }\end{array}$ \\
\hline \multirow[t]{5}{*}{1.} & Visual & $\begin{array}{l}\text { a. Ketepatan pemilihan teks (ukuran, } \\
\text { keterbacaan, dan kemenarikan) }\end{array}$ & 1,2 & 2 \\
\hline & & $\begin{array}{l}\text { b. Ketepatan dan kemenarikan gambar yang } \\
\text { digunakan }\end{array}$ & 3,4 & 2 \\
\hline & & c. Kombinasi warna yang digunakan & 5 & 1 \\
\hline & & d. Tampilan Multimedia & 6 & 1 \\
\hline & & e. Letak dan fungsi navigasi & 7,8 & \\
\hline \multirow[t]{2}{*}{2.} & Penggunaan & a. Aplikasi tidak sulit dioperasikan & 9 & 1 \\
\hline & & b. Aplikasi mudah diakses & 10 & 1 \\
\hline \multicolumn{2}{|c|}{ Jumlah } & & & $\mathbf{1 0}$ \\
\hline
\end{tabular}

Tabel 4. Kisi-Kisi Instrumen Uji Perorangan

\begin{tabular}{llll}
\hline No & Indikator & $\begin{array}{l}\text { Nomor } \\
\text { Item }\end{array}$ & $\begin{array}{l}\text { Jumlah } \\
\text { Butir }\end{array}$ \\
\hline 1 & $\begin{array}{l}\text { Ketercapaian tujuan dari penggunaan Quizizz pada kegiatan } \\
\text { penutup }\end{array}$ & $1,2,3$ & 3 \\
2 & Sikap siswa terhadap penggunaan Quizizz. & $4,5,6,7,8$ & 5 \\
\hline Jumlah & & $\mathbf{8}$ \\
\hline
\end{tabular}

Penelitian pengembangan ini menggunakan metode analisis deskriptif kuantitatif. Metode analisis deskriptif kuantiatif adalah suatu cara pengolahan data dengan menyusun data secara sistematis dalam bentuk kalimat, kata dan kategori sehingga ditemukan simpulan secara umum (Agung, 2014:110). Metode analisis ini digunakan untuk mengolah data hasil uji coba ahli isi muatan pelajaran, ahli desain instruksional, ahli media pembelajaran, dan uji coba perorangan. Data yang dimaksud yaitu skor-skor, saran, masukan, dan komentar yang terdapat pada kuesioner. Untuk memberikan makna atau kategori dari penelitian yang dilakukan, maka hasil uji coba diterjemahkan menggunakan tabel konversi skala 5, dengan ketentuan sebagai berikut.

Tabel 5. Konversi Tingkat Pencapaian dengan Skala 5

\begin{tabular}{lll}
\hline Tingkat Pencapaian \% & Kualifikasi & Keterangan \\
\hline $90-100$ & Sangat Baik & Sangat Layak \\
$80-89$ & Baik & Layak \\
\hline
\end{tabular}




\begin{tabular}{lll}
\hline Tingkat Pencapaian \% & Kualifikasi & Keterangan \\
\hline $65-78$ & Cukup Baik & Cukup Layak \\
$40-64$ & Tidak Baik & Tidak Layak \\
$00-39$ & Sangat Tidak Baik & Sangat Tidak Layak \\
\hline
\end{tabular}

\section{Hasil dan Pembahasan Hasil Penelitian}

Hasil penelitian pengembangan ini memperoleh dua hal pokok yaitu: (1) rancang bangun Multimedia Online, dan (2) validitas Multimedia Online. Dikarenakan dalam pengembangan produknya menggunakan model pengembangan ADDIE jadi rancang bangun Multimedia Online ini meliputi lima tahapan yaitu analisis (analyze), perancangan (design), pengembangan (development), implementasi (implementation), dan evaluasi (evaluation). Tahap analisis (analyze) merupakan tahap pertama dari model pengembangan ADDIE. Tujuan dari tahap analisis yaitu untuk mendapatkan informasi tentang kelengkapan sarana dan prasarana yang diperlukan untuk dijadikan pedoman dalam memecahkan masalah yang ditemukan dilapangan. Analisis dilakukan dengan metode observasi dan wawancara yang meliputi, analisis masalah pembelajaran, analisis lingkungan, serta fasilitas yang telah dimiliki di sekolah. Observasi dilaksanakan di kelas V SD Negeri 1 Bitera.dan wawancara dilakukan dengan guru wali kelas V. Pada masa pandemi COVID-19 ini, guru harus bisa memberikan suatu solusi maupun inovasi atas permasalahan yang ada di lapangan. Di dalam sistem pembelajaran daring seperti saat ini harus difasilitasi dengan sarana-prasarana pembelajaran yang mendukung terlaksananya pembelajaran daring, salah satunya adalah media pembelajaran. Permasalahan yang ditemukan di kelas V SD Negeri 1 Bitera yaitu kurangnya media pembelajaran yang bisa diterapkan dalam proses pembelajaran daring. Biasanya dalam pelaksanaan pembelajaran daring, hanya berorientasi pada grup WhatsApp dengan menggunakan metode penugasan. Selain menganalisis permasalahan pada proses pembelajaran, juga melakukan analisis fasilitas untuk mengetahui fasilitas pendukung dari pengembangan multimedia online pada pembelajaran IPA. Dari hasil observasi sebagian besar siswa sudah memiliki smartphone dengan sistem operasi android. Disamping itu fasilitas yang ada di SD Negeri 1 Bitera cukup lengkap yaitu terdapat akses internet WiFi. Hal tersebut menjadi aspek pendukung pengembangan Multimedia Online pada Pembelajaran IPA.

Tahap perancangan, sebelum melakukan pengembangan multimedia online pada pembelajaran IPA, ada rancangan dan prosedur atau langkah-langkah yang ditempuh untuk membuat suatu produk. Rancangan dan langkah-langkah dari pembuatan multimedia online pada pembelajaran IPA ini digambarkan dalam bentuk storyboard yang komunikatif. Pembuatan flowchart dan storyboard ini bertujuan untuk mempermudah memahami alur kerja dan prosedur pembuatan media yang akan dikembangkan. Tahap pengembangan, rancangan yang sudah dibuat pada tahap desain, selanjutnya akan diwujudkan ke dalam bentuk multimedia online. Pengembangan multimedia online pada pembelajaran IPA ini lebih difokuskan pada pengembangan media pembelajaran. Multimedia online pada pembelajaran IPA ini memuat menu tujuan pembelajaran, materi pembelajaran yang terdapat teks dan link video, soal latihan objektif dan disajikan menggunakan aplikasi Quizizz. Untuk pembuatan Multimedia dibuat pada aplikasi Adobe Flash CS6. Dalam pembuatan Multimedia ini dibuat semenarik mungkin agar siswa tertarik dan termotivasi dalam pembelajaran.

Tahap implementasi ini adalah kelanjutan dari tahap pengembangan. Pada tahap ini produk diuji cobakan untuk mengetahui respon dari pengguna produk. Sebelum produk diimplementasikan, produk divalidasi terlebih dahulu untuk mengetahui kelayakannya.. Dengan mempertimbangkan keterbatasan situasi dan kondisi di masa pandemi COVID-19, 
maka pengimplementasian produk hanya dilakukan pada uji perorangan saja. Pengimplementasian produk dengan siswa pada uji perorangan dilakukan melalui aplikasi Quizizz. Uji validitas Multimedia Online dilakukan untuk mengetahui tingkat kelayakan produk yang dikembangkan. Instrumen yang digunakan untuk mengetahui validitas produk berupa kuesioner. Validitas pengembangan Multimedia Online diuji oleh ahli isi muatan pelajaran, ahli desain instruksional, ahli media pembelajaran, dan subjek pada uji coba perorangan yang hasil rangkumannya tersaji pada Tabel 6. Adapun hasil pengembangan produk Multimedia Online terdiri dari, tampilan menu pembuatan kuis atau soal evaluasi di aplikasi Quizizz yang tersaji pada gambar 1 dan 2.

Tabel 6. Presentase Hasil Validitas Pengembangan Multimedia Online

\begin{tabular}{llll}
\hline No & Subjek Uji Coba & Hasil Validitas (\%) & Keterangan \\
\hline 1 & Uji Ahli Isi Muatan Pelajaran & 94,44 & Sangat Baik \\
2 & Uji Ahli Desain instruksional & 90,00 & Sangat Baik \\
3 & Uji Ahli Media Pembelajaran & 87,50 & Baik \\
4 & Uji Coba Perorangan & 92,67 & Sangat Baik \\
\hline
\end{tabular}

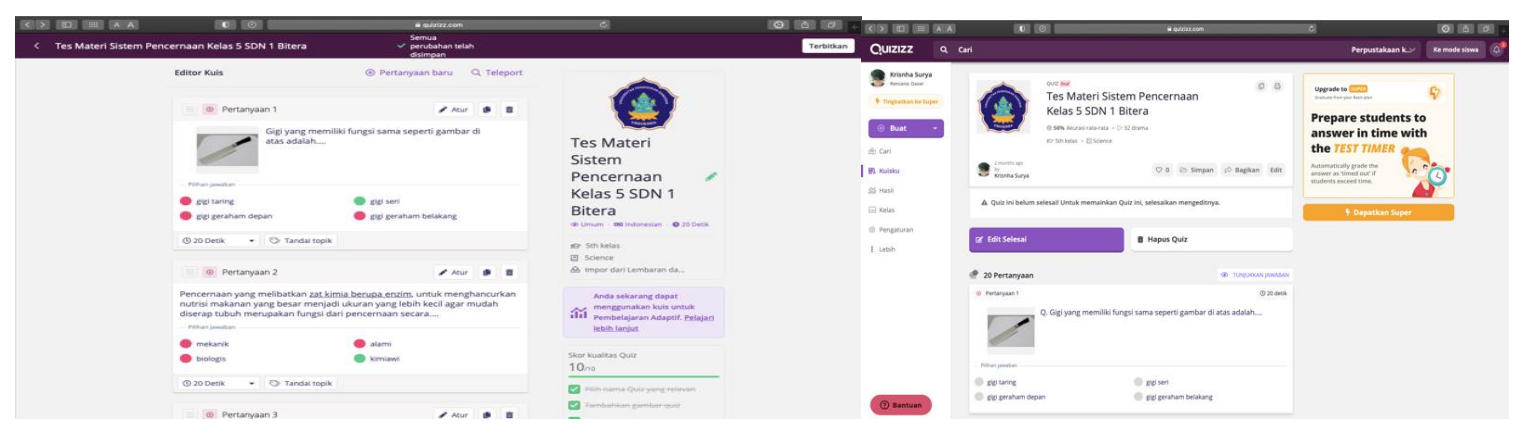

Gambar 1. Tampilan Menu Pembuatan Kuis atau Soal Evaluasi di Aplikasi Quizizz

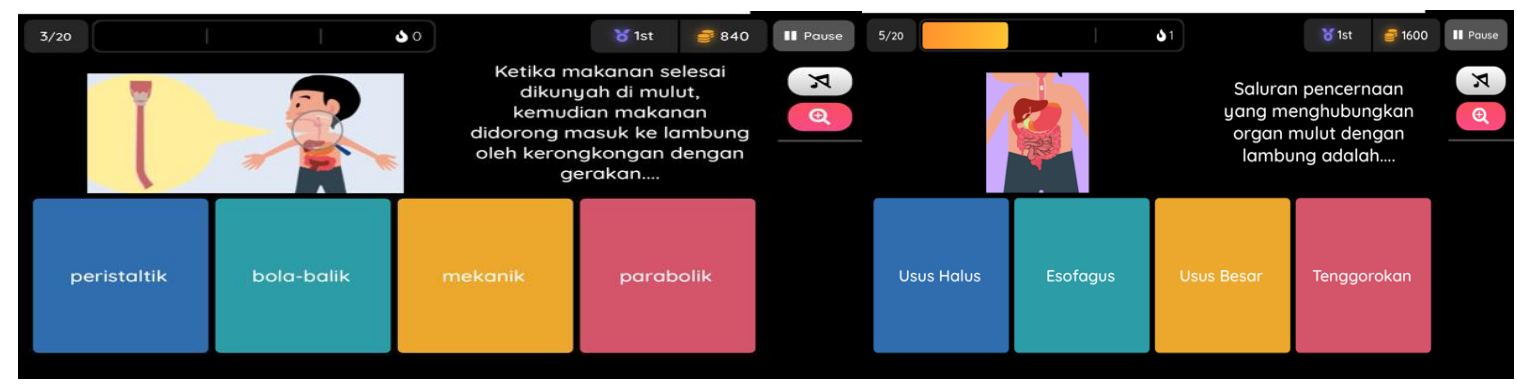

Gambar 2. Tampilan Kuis atau Soal Evaluasi di Aplikasi Quizizz

Validitas Multimedia Online ini ditentukan berdasarkan hasil evaluasi dari ahli meliputi: (1) ahli isi muatan pelajaran, (2) ahli desain instruksional, (3) ahli media pembelajaran, dan dari uji coba siswa yang hanya pada tahap (4) uji coba perorangan. Hasil tersebut diketahui dengan menggunakan metode kuesioner. Berdasarkan hasil review dari ahli isi muatan pelajaran IPA, diketahui bahwa Multimedia Online berada pada kualifikasi sangat baik yaitu 94,44\%. Berdasarkan hasil review dari ahli desain instruksional, diketahui bahwa Multimedia Online memperoleh persentase tingkat pencapaian 90,00\% dan berada pada kualifikasi sangat baik. Berdasarkan hasil review dari ahli media pembelajaran, diketahui bahwa Multimedia Online memperoleh persentase tingkat pencapaian 87,50\% dan berada pada kualifikasi baik. Setelah melewati hasil review para ahli, yaitu ahli isi muatan pelajaran IPA, ahli desain instruksional, dan ahli media pembelajaran, kemudian produk 
dapat diujocobakan kepada siswa. Tahap uji coba ini dilaksanakan hanya pada uji coba perorangan. Hasil validasi dalam uji coba perorangan mendapat persentase sebesar $92,67 \%$ dengan kualifikasi sangat baik.

\section{Pembahasan Hasil Penelitian}

Berdasarkan hasil hasil analisis data diperoleh dari ahli isi muatan pelajaran IPA, ahli desain instruksional, ahli media pembelajaran dan hasil uji coba perorangan memperoleh kualifikasi sangat baik. Maka dapat disimpulkan bahwa produk Multimedia Online pada Pembelajaran IPA ini layak digunakan pada kelas V. Produk ini layak digunakan disebabkan oleh beberapa faktor yaitu sebagai berikut.

Pertama, produk Multimedia Online pada pembelajaran IPA yang dikembangkan layak digunakan karena siswa dimudahkan dalam memahami materi pembelajaran. Pada produk Multimedia ini terdapat beberapa komponen seperti teks, gambar, audio, dan video yang digunakan untuk menunjang isi dari multimedia online pada pembelajaran IPA. Materi yang disajikan sesuai dengan tujuan pembelajaran. Sebelum melaksanakan proses pembelajaran tentunya guru harus membuat rencana kegiatan yang meliputi: penentuan tujuan pembelajaran, menentukan bahan pelajaran, menentukan alat dan metode pembelajaran, dan merencanakan penilaian pembelajaran (Rusman, 2013). Melalui kegiatan yang disusun secara sistematis maka diharapkan tujuan pembelajaran dapat tercapai dan proses pembelajaran berjalan secara kondusif. Selain itu Glasser mengungkapkan guru harus bisa menguasai empat kompetensi sebelum melakukan proses pembelajaran yaitu menguasai bahan pelajaran, mampu mendiagnosis tingkah laku siswa, mampu melaksanakan proses pembelajaran, dan mampu mengevaluasi hasil belajar siswa.

Kedua, produk Multimedia Online pada Pembelajaran IPA yang dikembangkan layak digunakan disebabkan produk ini menarik. Kesesuaian isi materi, kelengkapan materi dan keruntutan materi dalam multimedia online pada pembelajaran IPA ini sesuai. Kemudian aspek kebahasaan dalam media pembelajaran ini sesuai. Selanjutnya dari aspek ketepatan pemilihan video, kualitas soal, dan proporsi soal dalam multimedia online pada pembelajaran IPA tepat dan sesuai. Senada seperti yang dikatakan oleh bahwa dalam mendesain kegiatan pembelajaran haruslah melakukan analisis terlebih dahulu seperti melakukan analisis kebutuhan siswa dan menganalisis masalah-masalah terkait proses pembelajaran (Trianto, 2009:183). Pada abad 21 ini guru dituntut untuk dapat menguasai berbagai keterampilan mengajar, salah satunya yaitu mampu memanfaatkan teknologi informasi dan komunikasi (TIK). Teknologi informasi bisa membantu guru untuk mengilustrasikan informasi yang ingin disampaiakan (Khuzaini \& Santosa, 2016). Menggunakan bahan ajar yang modern seperti menggunakan unsur audio visual bisa menarik perhatian siswa (Jumasa \& Surjono, 2016).

Temuan penelitian lain menyatakan multimedia dapat meningkatkan berpikir kreatif pada siswa dan memudahkan siswa dalam menyerap informasi (Rasyid et al., 2016). Penelitian ini didukung dari hasil penelitian yang telah dilakukan sebelumnya oleh yang menggunakan aplikasi Quizizz untuk mengembangankan bahan ajar LKPD. Penelitian tersebut menunjukan bahwa LKPD yang dikembangkan layak digunakan (Kinanti \& Subagio, 2020). Menggunakan aplikasi Quizizz dalam pembelajaran juga terbukti meningkatkan hasil belajar (Jati, 2020;Mulyati \& Evendi, (2020). Dapat disimpulkan bahwa multimedia pembelajaran dapat memudahkan siswa dalam belajar sehingga berdampak pada hasil belajar siswa. Media pembelajaran memegang peran yang sangat penting dalam penyampaian informasi dalam proses pembelajaran. Media pembelajaran yang menarik dan interaktif dapat motivasi siswa dalam belajar (Kuswanto dkk., 2017). Implikasi penelitian ini yaitu memberikan fasilitas media pembelajaran berupa multimedia yang membantu siswa 
dalam belajar karena dapat menfasilitasi kebutuhan belajar siswa. Multimedia pembelajaran mampu meningkatkan kompetensi siswa dan hasil belajar siswa.

\section{Simpulan}

Penelitian pengembangan ini menghasilkan produk Multimedia Online pada muatan pelajaran IPA SD. Berdasarkan hasil validasi produk oleh para ahli dan hasil uji coba perorangan, menunjukan bahwa produk Multimedia Online ini layak digunakan pada muatan pelajaran IPA kelas V.

\section{Daftar Rujukan}

Agung, A. A. G. (2014). Metodologi Penelitian Pendidikan. Aditya Media Publishing.

Ahmadi, F., Sutaryono, Witanto, Y., \& Ratnaningrum, I. (2017). Pengembangan Media Edukasi "Multimedia Indonesian Culture" (Mic) Sebagai Penguatan Pendidikan Karakter Siswa Sekolah Dasar. Jurnal Penelitian Pendidikan, 34(2), 127-136. https://doi.org/10.15294/jpp.v34i2.12368.

Budiman, H. (2017). Peran Teknologi Informasi Dan Komunikasi Dalam Pendidikan. AlTadzkiyyah: Jurnal Pendidikan $\quad$ Islam, 31. https://doi.org/10.24042/atjpi.v8i1.2095.

Citra, C. A., \& Rosy, B. (2020). Keefektifan Penggunaan Media Pembelajaran Berbasis Game Edukasi Quizizz Terhadap Hasil Belajar Teknologi Perkantoran Siswa Kelas X SMK Ketintang Surabaya. Jurnal Pendidikan Administrasi Perkantoran (JPAP), 8, 261-272. https://journal.unesa.ac.id/index.php/jpap/article/view/8242.

Jati, D. H. P. (2020). Peningkatan Hasil Belajar Ppkn Melalui Pembelajaran Online Berbasis Quizizz. Jurnal Mitra Pendidikan, 4(1), 1-9. https://doi.org/10.52160/e-jmp.v4i5.737

Jumasa, M. A., \& Surjono, H. D. (2016). Pengembangan Multimedia Pembelajaran Bahasa Inggris Untuk Pembelajaran Teks Recount Di MTSN II Yogyakarta. Jurnal Inovasi Teknologi Pendidikan, 3(1), 25. https://doi.org/10.21831/tp.v3i1.8287.

Khuzaini, N., \& Santosa, R. H. (2016). Pengembangan Multimedia Pembelajaran Trigonometri Menggunakan Adobe Flash Cs3 Untuk Siswa SMA. Jurnal Riset Pendidikan Matematika, 3(1), 88. https://doi.org/10.21831/jrpm.v3i1.9681.

Kinanti, M. D., \& Subagio, F. M. (2020). Pengembangan Lkpd Bahasa Inggris Berbantu Aplikasi Quizizz Kelas Iv Sekolah Dasar. Jurnal PGSD, 8(3), 539-548. https://jurnalmahasiswa.unesa.ac.id/index.php/jurnal-penelitianpgsd/article/view/35318.

Kuswanto, J., Walusfa, Y., Artikel, S., Korespondensi, A., Ratu Penghulu No, J., Sari, K., Baru, T., Raja Tim, B., Ogan Komering Ulu, K., \& Selatan, S. (2017). Pengembangan Multimedia Pembelajaran pada Mata Pelajaran Teknologi Informasi dan Komunikasi Kelas VIII. Innovative Journal of Curriculum and Educational Technology IJCET, 6(2), 58-64. https://journal.unnes.ac.id/sju/index.php/ujet/article/view/19335.

Muhammad, S. (2020). Pandemi Covid-19 Dan Implikasinya Terhadap Pembelajaran Pendidikan Agama Islam (Studi Kasus Pada Siswa Smp N 1 Banyubiru Kabupaten Semarang) Tahun 2020. PT Remaja Rosdakarya, 2(4), 108. http://erepository.perpus.iainsalatiga.ac.id/8988/.

Mulyati, S., \& Evendi, H. (2020). Pembelajaran Matematika Melalui Media Game Quizizz Untuk Meningkatkan Hasil Belajar Matematika Smp 2 Bojonegara. Jurnal Pendidikan Matematika, 03(01), 64-73. https://doi.org//10.30656/gauss.v3i1.2127.

Novianto, L. A., Degeng, I. N. S., \& Wedi, A. (2018). Pengembangan Multimedia Interaktif Mata Pelajaran IPA Pokok Bahasan Sistem Peredaran Darah Manusia Untuk Kelas VIII SMP Wahid Hasyim Malang. Jurnal Kurikulum Teknologi Pendidikan (JKTP) Universitas Negeri $\quad$ Malang, 257-263. 
http://journal2.um.ac.id/index.php/jktp/article/view/5770.

Novita, Sukmanasa, \& P. (2019). Penggunaan Media Pembelajaran Video Terhadap Hasil Belajar Siswa SD. Indonesian Journal of Primary Education, 3(2), 64-72. https://ejournal.upi.edu/index.php/IJPE/article/view/22103.

Permana, E. P., \& Nourmavita, D. (2017). Pengembangan Multimedia Interaktif Pada Mata Pelajaran Ipa Materi Mendeskripsikan Daur Hidup Hewan Di Lingkungan Sekitar Siswa Kelas Iv Sekolah Dasar. Jurnal PGSD, 10(2), 79-85. https://doi.org/10.33369/pgsd.10.2.79-85.

Rasyid, M., Azis, A., \& Saleh, A. (2016). Pengembangan Media Pembelajaran Berbasis Multimedia Dalam Konsep Sistem Indera Pada Siswa Kelas XI SMA. Jurnal Pendidikan Biologi, 7(2), 69-80. https://doi.org/10.17977/um052v7i2p69-80.

Rosidah, A. (2016). Penerapan Media Pembelajaran Visual Untuk Meningkatkan Pemahaman Konsep Siswa Pada Mata Pelajaran IPS. Jurnal Cakrawala Pendas, 2(2). https://doi.org/10.31949/jcp.v2i2.499.

Rusman. (2013). Pembelajaran Berbasis teknologi informasi dan komunikasi. Rajawali Pers.

Santika, I. G. N. (2021). Grand Desain Kebijakan Strategis Pemerintah Dalam Bidang Pendidikan Untuk Menghadapi Revolusi Industri 4.0. Jurnal Education and Development, 9(2), 369-377. https://doi.org/10.37081/ed.v9i2.2500.

Saurina. (2016). Pengembangan Media Pembelajaran Untuk Anak Usia Dini Menggunakan Augmented Reality. Jurnal IPTEK, 20(1), 95-108. https://doi.org/10.31284/j.iptek.2016.v20i1.27.

Simarmata, J., \& Mujiarto. (2019). Multimedia Pembelajaran. CV Alfabeta.

Sudihartono, Y. (2020). Penerapan Quizizz Dalam Pelaksanaan Penilaian Pengetahuan Peserta Diklat Di Badan Pengembangan Sumber Daya Manusia Daerah Provinsi Sumatera Selatan. Jurnal Lentera Pendidikan Pusat Penelitian, 5(1), 1-15.

Susilo, A., Rumende, C. M., Pitoyo, C. W., Santoso, W. D., Yulianti, M., Herikurniawan, H., Sinto, R., Singh, G., Nainggolan, L., Nelwan, E. J., Chen, L. K., Widhani, A., Wijaya, E., Wicaksana, B., Maksum, M., Annisa, F., Jasirwan, C. O. M., \& Yunihastuti, E. (2020). Coronavirus Disease 2019: Tinjauan Literatur Terkini. Jurnal Penyakit Dalam Indonesia, 7(1), 45. https://doi.org/10.7454/jpdi.v7i1.415.

Tegeh, I. M., \& Kirna, I. M. (2013). Pengembangan Bahan Ajar Metode Penelitian Pendidikan dengan ADDIE Model. Jurnal Pendidikan, 11(1), 16. http://dx.doi.org/10.23887/ika.v11i1.1145.

Trianto. (2009). Mendesaian Model Pembelajaran Inovatif Progresif. Kencana Prenada Media Group.

Widjiningsih, Sugiyono, \& G. (2014). Efektivitas Dan Efisiensi Pembelajaran Teknik Draping Berbantuan Video. Di Perguruan Tinggi. Cakrawala Pendidikan, 1(33), 6270. https://doi.org/10.21831/cp.v1i1.1862.

Wisudawati, W., \& Sulistyowati, E. (2015). Metodologi Pembelajaran IPA. Bumi Aksara.

Yana, A. U., Antasari, L., \& Kurniawan, B. R. (2019). Analisis Pemahaman Konsep Gelombang Mekanik Melalui Aplikasi Online Quizizz. Jurnal Pendidikan Sains Indonesia (Indonesian Journal of Science Education), 7(2), 143-152. https://doi.org/10.24815/jpsi.v7i2.14284.

Yusnia, Y. (2019). Penggunaan Media Video Scribe Dalam Pembelajaran Literasi Sains Untuk Mahasiswa PGPAUD. Cakrawala Dini: Jurnal Pendidikan Anak Usia Dini, 10(1), 71-75. https://doi.org/10.17509/cd.v10i1.17436. 